\title{
Rancang Bangun Robot Pemadam Api Menggunakan Kontrol Bluetooth dan Virtual Reality
}

\section{Design and Implementation of Fire Extinguisher Robot Using Bluetooth Control and Virtual Reality}

\author{
Denni Kurnia $^{1 *}$, Rina Mardiati ${ }^{2}$, Mufid Ridlo Effendi ${ }^{3}$, Aan Eko Setiawan ${ }^{4}$ \\ 1,2,3 Teknik Elektro, Sains dan Teknologi, UIN Sunan Gunung Djati \\ Bandung, 022-7800525 \\ ${ }^{4}$ Program Pasca Sarjana, Telkom University \\ dennikurnia458@gmail.com ${ }^{1 *}$, r_mardiati@uinsgd.ac.id², mufid.ridlo@uinsgd.ac.id ${ }^{3}$, aneko37@gmail.com ${ }^{4}$
}

\begin{abstract}
Abstrak - Robot bermanfaat untuk membantu manusia dalam melakukan pekerjaan yang membutuhkan ketelitian tinggi, membutuhkan tenaga besar, pekerjaan yang berulang, dan pekerjaan yang berbahaya. Saat ini, robot dikembangkan dengan berbagai desain dengan tujuan-tujuan tertentu, salah satunya adalah robot pemadam api. Robot pemadam api yang sudah dikembangkan sebelumnya, pada umumnya sistem navigasinya berbasis otonom. Pada penelitian ini akan dilakukan sebuah rancang bangun robot pemadam api yang berbasis mikrokontroler Arduino Uno, dengan kontrol navigasi oleh manusia (tidak otonom) melalui Bluetooth. Piranti penglihatan robot pemadam api dibangun menggunakan Virtual Reality Box yang dipakai oleh user untuk mengarahkan gerak robot pemadam api. Instruksi pergerakan robot yang dilakukan oleh user dikirim ke sistem robot melalui Bluetooth. Selain dari itu, robot pemadam api yang dibangun memiliki fitur tambahan proteksi menggunakan sensor ultrasonik, yang berfungsi sebagai fungsi yang melindungi robot dari tabrakan. Fitur proteksi ini akan berfungsi mengunci gerakan robot, jika terdeteksi objek penghalang pada jarak tertent, sehingga instruksi dari user tidak akan dieksekusi jika fitur proteksi ini sedang dalam status on. Pada penelitian ini, dilakukan beberapa pengujian untuk mengetahui kinerja fungsi-fungsi robot yang sudah dibangun. Berdasarkan hasil pengujian secara keseluruhan, diperoleh bahwa fungsi-fungsi dan fitur yang dibangun pada robot ini memiliki kinerja yang baik, dan berjalan sesuai tujuan yang ingin dicapai. Kesimpulan khusus, bahwa komunikasi user dengan robot pemadam api melalui koneksi Bluetooth memiliki kinerja baik pada rentang maksimal 16 meter.
\end{abstract}

Kata Kunci: Arduino Uno, Bluetooth, Flame sensor, Robot, Ultrasonik, VR .

\begin{abstract}
Robots are useful to assist humans in doing work that requires high accuracy, large energy, repetitive work, and dangerous work. Currently, robots are developed with various designs with specific objectives, one of which is a fire extinguisher robot. In previous work, mainly the navigation system of fire extinguisher robot is based on autonomous. In this research, a fire extinguisher robot design based on Arduino Uno microcontroller with navigation control by humans (not autonomous) via Bluetooth. The fire extinguisher robot's vision device was built using a Virtual Reality Box that will used by the user to direct the motion of the fire extinguisher robot. The user's robot movement instructions are sent to the robot
\end{abstract}

TELKA, Vol.5, No.2, November 2019, pp. 139 146

ISSN (e): 2540-9123

ISSN (p): 2502-1982 
system via Bluetooth. Apart from that, the fire extinguisher robot that is built has an additional protection feature using an ultrasonic sensor, which protects the robot from collisions. This protection feature will function to lock the robot's movement, if a barrier object is detected at a certain distance, so that instructions from the user will not be executed if this protection feature is on. In this study, several tests were conducted to determine the performance of the robot functions that had been built. Based on the overall test results, it was found that the functions and features built on this robot have good performance, and run according to the objectives to be achieved. Specific conclusion, that the user communication with a fire extinguisher robot via a Bluetooth connection has good performance in the maximum range of 16 meters.

Keywords: Arduino Uno, Bluetooth, Flame sensor, Robot, Ultrasonic, VR.

\section{Pendahuluan}

Teknologi adalah sebuah pengetahuan yang ditujukan untuk menciptakan alat, tindakan pengolahan dan ekstraksi benda. Selain dari itu, teknologi dapat didefinisikan sebagai cara untuk mendapatkan sesuatu dengan kualitas yang lebih baik. Salah satu teknologi yang berkembang pesat saat ini adalah teknologi dibidang robotik. Robot bermanfaat untuk membantu manusia dalam melakukan pekerjaan yang membutuhkan ketelitian tinggi, membutuhkan tenaga besar, pekerjaan yang berulang, dan pekerjaan yang beresiko tinggi/berbahaya. Salah satu pekerjaan manusia yang beresiko tinggi yang dapat dilakukan oleh robot adalah pemadam kebakaran [1].

Robot pemadam api adalah alat yang membantu manusia untuk menelusuri, mendeteksi dan memadamkan api. Pengembangan robot pemadam api memerlukan alat pendeteksi yang memiliki akurasi tinggi untuk mendeteksi api. Tingkat akurasi robot pendeteksi api dapat dipengaruhi oleh input-an yang diterima dari sensor yang tertanam pada robotpemadam api. Sensor untuk mendeteksi api diantaranya adalah dengan menggunakan sensor suhu, gelombang infrared serta panas dari api [2 - 3]. Disamping itu, dalam proses pencarian sumber api juga diperlukan sebuah sensor jarak (ping ultrasonic) yang berfungsi sebagai sistem proteksi, dimana sistem proteksi ini digunakan untuk menjaga robot agar tidak menabrak penghalang [4].

Pengembangan robot pemadam api sudah banyak dikembangkan sebelumnya oleh penelitipeneliti di bidang robotik. Suryatini dkk, pada penelitiannya mengembangkan sebuah robot pemadam api dengan mengecek apakah dalam sebuah ruangan terdapat api atau tidak [5]. Selanjutnya, pencarian titik api dilakukan dengan mendeteksi pancaran sinar ultraviolet yang dipancarkan oleh api dengan menggunakan sensor UVTron flame detector. Proses pemadaman api dilakukan menggunakan kipas yang digerakkan oleh motor DC. Beberapa penelitian lain yang juga mengembangkan robot pemadam api menggunakan konsep yang hampir mirip yaitu dengan menggunakan flame sensor ataupun flame detector yang diintegrasikan dengan mikrokontroller sudah pernah dikembangkan $[1,6,7]$.

Berdasarkan literatur yang sudah dikembangkan sebelumnya, mayoritas sistem navigasi robot pemadam api bersifat otonom. Robot pemadam api dikembangkan dengan berbagai metode dan pendekatan dalam upaya pengoptimalisasian kinerja dari robot pemadam api $[3,4,5,6]$. Namun, apabila robot pemadam api ini selanjutnya akan dikembangkan untuk robot dengan skala yang lebih besar dengan maksud untuk robot pemadam api kebakaran, maka diperlukan sistem navigasi yang dapat dikontrol oleh manusia, sehingga pergerakan robot lebih fleksibel disesuaikan dengan keinginan user. Oleh karena itu, pada penelitian ini akan dikembangkan sebuah robot pemadam api dengan sistem navigasi dikendalikan oleh manusia (tidak bersifat otonom). Piranti penglihatan robot pemadam api dibangun menggunakan Virtual Reality Box yang dipakai oleh user untuk mengarahkan gerak robot pemadam api. Instruksi pergerakan robot yang dilakukan oleh user dikirim ke sistem robot melalui Bluetooth. Selain dari itu, robot pemadam api yang dibangun memiliki fitur tambahan proteksi menggunakan sensor ultrasonik, yang berfungsi sebagai fungsi yang melindungi robot dari tabrakan. Fitur proteksi ini akan berfungsi mengunci gerakan robot, jika terdeteksi objek penghalang pada jarak tertent, sehingga instruksi dari user tidak akan dieksekusi jika fitur proteksi ini sedang dalam status on. 


\section{Metode Penelitian}

Tahapan penting dalam pelaksanaan penelitian ini meliputi: studi literatur, rumusan masalah, perancangan sistem deteksi, pengujian, realisasi, analisis yang dapat dilihat pada Gambar 1. Pada penelitian ini, dibangun pemrograman sederhana untuk konfigurasi sensor jarak pada sistem proteksi navigasi robot, sensor api untuk pendeteksian api serta program fan motor driver untuk menggerakan kipas. Semua rancangan ini menggunakan Bahasa pemograman $\mathrm{C}$ di Arduino Uno 1.8.4.

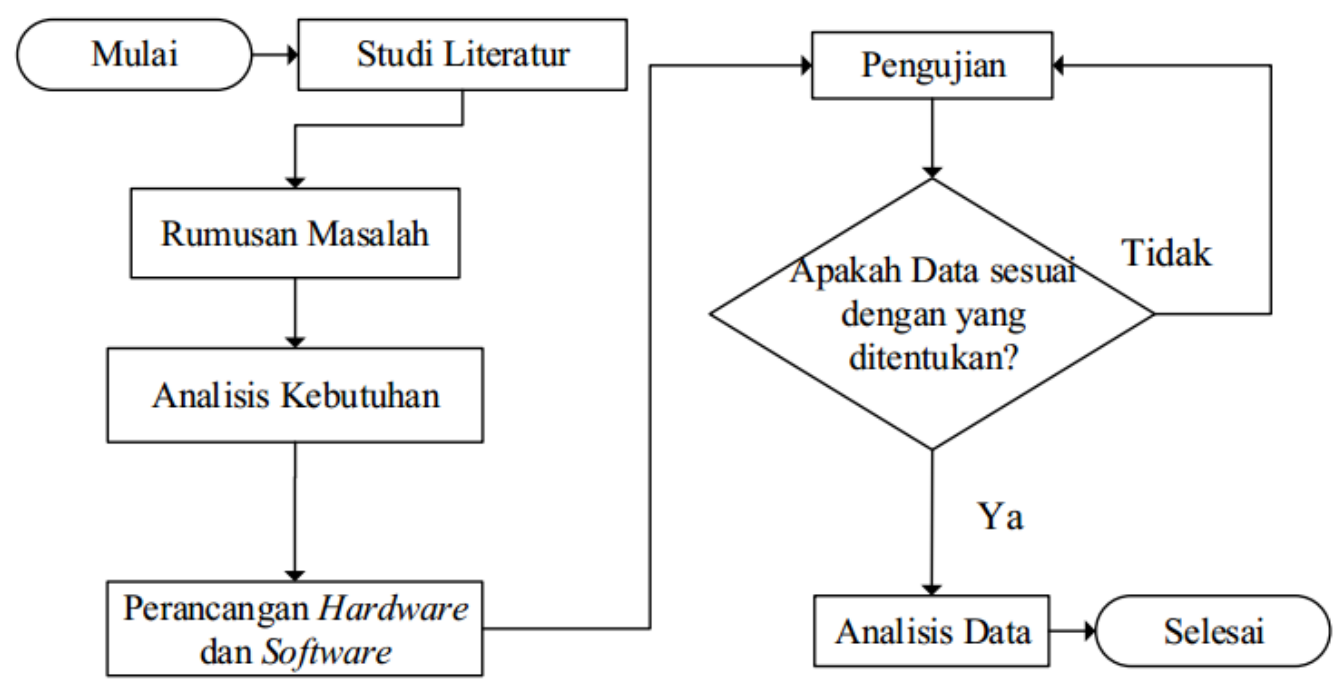

Gambar 1. Metodologi penelitian.

\section{Perancangan}

Perancangan dan implementasi merupakan tahapan dari proses dalam pembuatan alat. Perancangan digunakan untuk menentukan komponen penyusun dari suatu alat yang akan dibuat, sehinggga hasil akhirnya sesuai dengan yang diinginkan. Setelah mengumpulkan beberapa referensi dan menganalisis kebutuhan untuk pembuatan alat, maka pada perancangan alat terdapat beberapa tahapan yang telah dilakukan secara umum. Tahapan pada perancangan sistem ini meliputi perancangan hardware dan perancangan software, dimana pada bagian perancangan hardware akan dibahas mengenai perancangan perangkat elektronik pada robot bagian atas dan bagian bawah yang terdiri dari sensor flame detector KY-026, sensor ultrasonik HC SR-04, motordriver L298N, fan motordriver dan kamera drone VISUO XS809S. Sedangkan pada perancangan software mengenai program dan setting kinerja dari kinerja robotnya.

Perancangan robot pendeteksi dan pemadam api menggunakan Bluetooth dan VR ini terdiri dari 3 blok sistem yaitu: input, proses dan output. Blok sistem input adalah modul bluetooth, dimana modul tersebut akan mendapatkan intruksi dari smartphone, kemudian sensor, dimana sensor tersebut terdiri dari sensor ultrasonik dan sensor api untuk mendeteksi jarak dan mendeteksi api. Proses adalah tindakan lanjutan yang berasal dari sensor tersebut, kemudian akan diproses pada Arduino Uno dan output adalah sebuah tindakan yang dilakukan oleh robot untuk bergerak, mendeteksi dan memadamkan api. Gambar 2 menjelaskan perancangan blok diagram sistem robot pendeteksi dan pemadam api menggunakan kontrol Bluetooth dan VR sedangkan Gambar 3 merupakan skema rangkaian robot secara keseluruhan. 


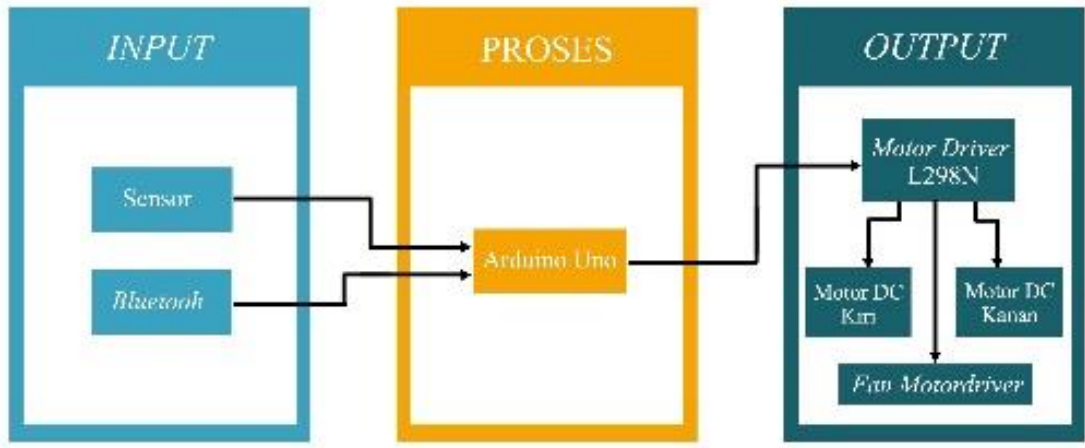

Gambar 2. Diagram blok sistem yang dibangun.

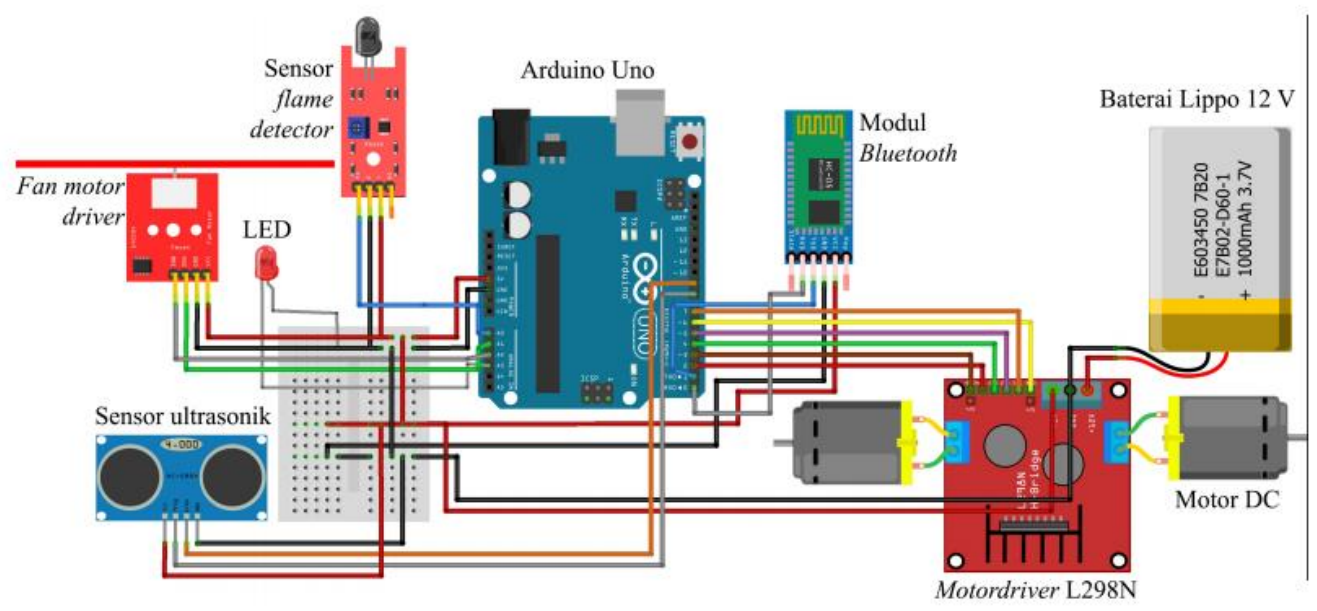

Gambar 3. Skema rangkaian robot.

\subsection{Perancangan Hardware Robot}

Perancangan hardware pada Robot terdiri dari dua bagian yaitu mekanik rangkaian bagian atas dan bagian bawah Robot berbahan dasar akrilik. Dengan ukuran $14 \mathrm{~cm} \times 15,5 \mathrm{~cm}$, dengan tinggi Robot $7 \mathrm{~cm}$. Robot didesain menjadi 2 bagian, seperti pada Gambar 4 .

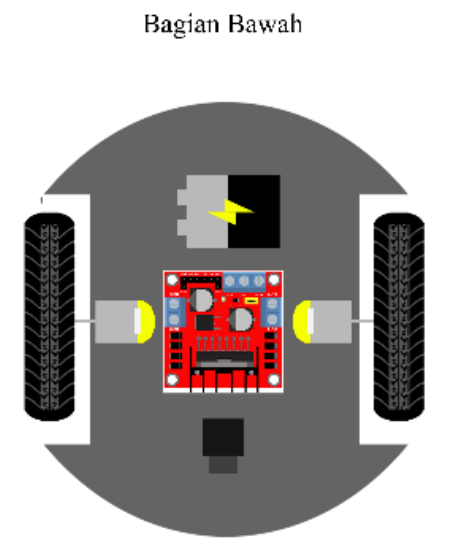

a

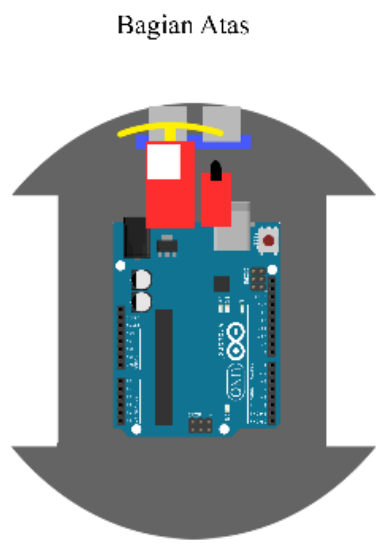

b

Gambar 4. Rangkaian robot : (a) robot bagian bawah (b) robot bagian atas. 


\subsection{Perancangan Software Robot}

Setelah dilakukan perancangan hardware robot bagian atas dan bawah, selanjutnya ke bagian perancangan software. Adapun software yang dipakai dalam penelitian ini yaitu sebagai berikut IDE Arduino Arduino 1.8.4. IDE Arduino yang digunakan untuk membuat program dan mengirimkan hasil kompilasi programnya ke Arduino Uno, dan software Fritzing yang digunakan untuk melakukan perancangan skema rangkaian dari bangun robot.

\subsection{Flowchart Program Robot}

Sebagai penunjang kinerja dari rancang bangun robot pemadam api menggunakan kontrol bluetooth dan VR maka harus dibuat program terlebih dahulu. Program dibuat pada software Arduino IDE dengan menggunakan bahasa C. sebelum membuat program terlebih dahulu dilakukan pembuatan flowchart program dari rancang bangun robot ini. Diagram alir program rancang bangun robot dilihat pada Gambar 5.

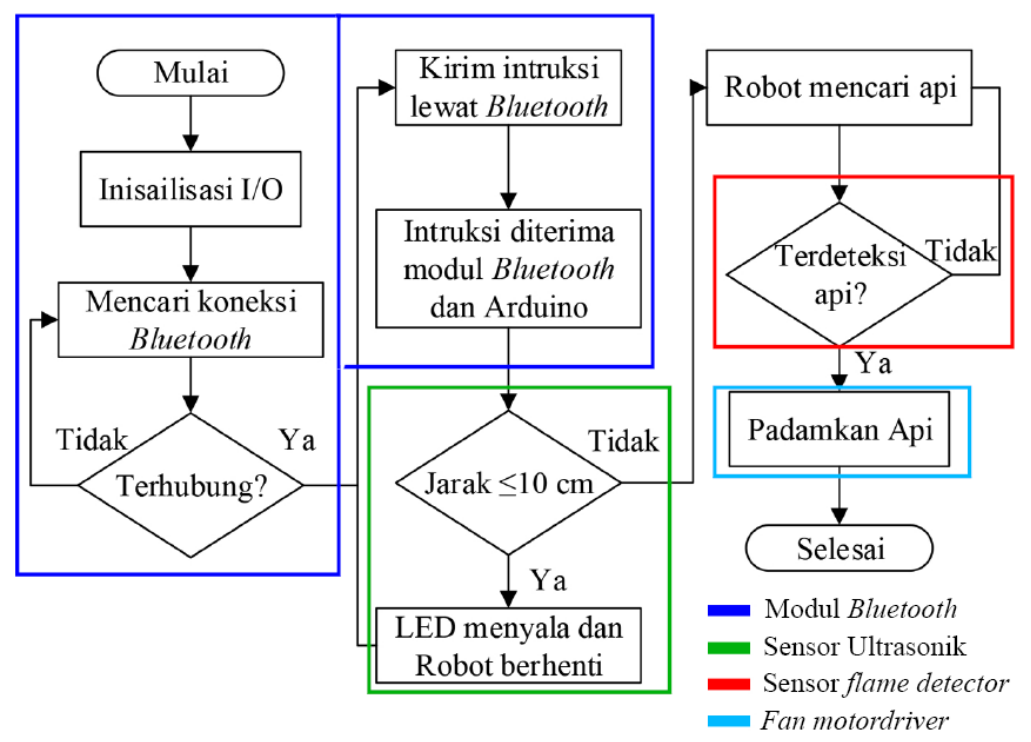

Gambar 5. Flowchart program.

\subsection{Implementasi}

Setelah perancangan sistem dari robot pendeteksi dan pemadam api selanjutnya akan dilakukan implementasi atau realisasi perancangan. Dalam implementasi rancangan ini akan dibagi menjadi dua, yaitu implementasi hardware atau perangkat keras dan implementasi software atau bahasa pemograman dengan menggunakan bahasa C. Gambar 6. merupakan implementasi dari rangkaian robot bagian atas dan bagian bawah.

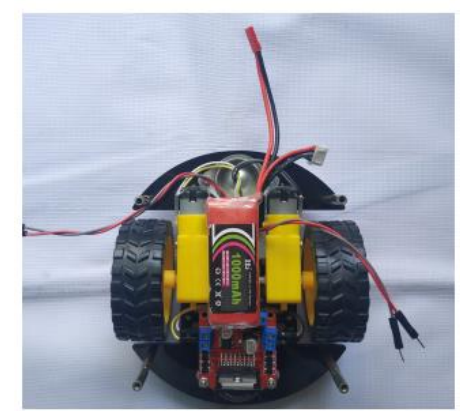

(a)

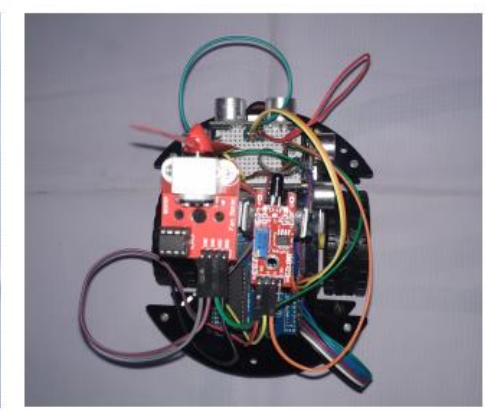

(b)

Gambar 11. Rangkaian robot : (a) robot tampak bawah (b) robot tampak atas. 


\section{Pengujian dan Analisis}

Penelitian ini dilakukan untuk memperoleh akurasi sensor dan pengujian sistem secara keseluruhan. Pengujian robot secara keseluruhan terdiri dari pengujian konektivitas bluetooth, keakuratan sensor api dan sistem proteksi. Pada pengujian konektivitas bluetooth dilakukan beberapa percobaan untuk mengetahui apakah modul bluetooth bekerja dengan baik atau tidak setelah terintegrasi dengan seluruh komponen robot. Adapun pengujian yang dilakukan untuk modul bluetooth ini adalah untuk mengetahui respon dari smartphone ketika mengontrol robot dengan pengukuran jarak memakai meteran. Tabel 1 menunjukkan hasil dari pengujian konektivitas Bluetooth HC-05 dengan halangan beton dan Tabel 2 menunjukkan hasil dari pengujian konektivitas Bluetooth $\mathrm{HC}-05$ dengan halangan papan triplek.

Tabel 1. Pengujian konektivitas kontrol bluetooth dengan halangan beton.

\begin{tabular}{cccccc}
\hline $\begin{array}{c}\text { Pengujian } \\
\text { ke- }\end{array}$ & Jarak(m) & Kontrol robot & $\begin{array}{c}\text { Pengujian } \\
\text { ke- }\end{array}$ & Jarak(m) & Kontrol robot \\
\hline 1 & 1 & Berfungsi & 11 & 11 & Berfungsi \\
2 & 2 & Berfungsi & 12 & 12 & Tidak Berfungsi \\
3 & 3 & Berfungsi & 13 & 13 & Tidak Berfungsi \\
4 & 4 & Berfungsi & 14 & 14 & Tidak Berfungsi \\
5 & 5 & Berfungsi & 15 & 15 & Tidak Berfungsi \\
6 & 6 & Berfungsi & 16 & 16 & Tidak Berfungsi \\
7 & 7 & Berfungsi & 17 & 17 & Tidak Berfungsi \\
8 & 8 & Berfungsi & 18 & 18 & Tidak Berfungsi \\
9 & 9 & Berfungsi & 19 & 19 & Tidak Berfungsi \\
10 & 10 & Berfungsi & 20 & 20 & Tidak Berfungsi \\
\hline
\end{tabular}

Tabel 2. Pengujian konektivitas kontrol bluetooth dengan halangan triplek.

\begin{tabular}{cccccc}
\hline $\begin{array}{c}\text { Pengujian } \\
\text { ke- }\end{array}$ & Jarak(m) & Kontrol robot & $\begin{array}{c}\text { Pengujian } \\
\text { ke- }\end{array}$ & Jarak(m) & Kontrol robot \\
\hline 1 & 1 & Berfungsi & 11 & 11 & Berfungsi \\
2 & 2 & Berfungsi & 12 & 12 & Berfungsi \\
3 & 3 & Berfungsi & 13 & 13 & Berfungsi \\
4 & 4 & Berfungsi & 14 & 14 & Berfungsi \\
5 & 5 & Berfungsi & 15 & 15 & Berfungsi \\
6 & 6 & Berfungsi & 16 & 16 & Tidak Berfungsi \\
7 & 7 & Berfungsi & 17 & 17 & Tidak Berfungsi \\
8 & 8 & Berfungsi & 18 & 18 & Tidak Berfungsi \\
9 & 9 & Berfungsi & 19 & 19 & Tidak Berfungsi \\
10 & 10 & Berfungsi & 20 & 20 & Tidak Berfungsi \\
\hline
\end{tabular}

Berdasarkan Tabel 1, dilakukan pengujian konektivitas kontrol Bluetooth dengan halangan beton dengan variasi jarak 1 sampai dengan 20 meter. Berdasarkan hasil pengujian diperoleh bahwa kontrol navigasi robot melalui Bluetooth dapat berfungsi dengan baik pada rentang 0-11 meter. Sedangkan pada Tabel 2, hasil pengujian konektivitas kontrol Bluetooth dengan halangan papan triplek dapat berfungsi dengan baik pada rentang jarak 0-15 meter.

Selanjutnya, dilakukan pengujian keakuratan sensor api dalam mendeteksi api. Modul sensor api yang digunakan adalah IR KY-026, yang berbasis infrared. Selain mendeteksi api, dilakukan juga setting terhadap pemutaran kipas pada robot berdasarkan nilai logic yang dihasilkan pada sensor ini. Pemutaran kipas pada robot akan dilakukan untuk nilai logic kurang dari 60. Tabel 3 menunjukkan bahwa fungsi sensor api berjalan sesuai settingan yang dilakukan sebelumnya. 
Tabel 3. Pengujian kinerja sensor api.

\begin{tabular}{ccccc}
\hline $\begin{array}{c}\text { Percobaan } \\
\text { ke- }\end{array}$ & Jarak(cm) & Nilai Logic & Sensor Api & Kipas pada Robot \\
\hline 1 & 2 & 42 & Terdeteksi & Menyala \\
2 & 4 & 43 & Terdeteksi & Menyala \\
3 & 6 & 50 & Terdeteksi & Menyala \\
4 & 8 & 51 & Terdeteksi & Menyala \\
5 & 10 & 54 & Terdeteksi & Menyala \\
6 & 12 & 54 & Terdeteksi & Menyala \\
7 & 14 & 67 & Terdeteksi & Tidak Menyala \\
8 & 16 & 91 & Terdeteksi & Tidak Menyala \\
9 & 18 & 145 & Terdeteksi & Tidak Menyala \\
10 & 20 & 194 & Terdeteksi & Tidak Menyala \\
11 & 22 & 196 & Terdeteksi & Tidak Menyala \\
12 & 24 & 203 & Terdeteksi & Tidak Menyala \\
13 & 26 & 221 & Terdeteksi & Tidak Menyala \\
14 & 28 & 276 & Terdeteksi & Tidak Menyala \\
15 & 30 & 364 & Terdeteksi & Tidak Menyala \\
\hline
\end{tabular}

Pengujian terakhir dilakukan untuk menguji kinerja dari sensor ultrasonik HC-SR 04 yang berfungsi sebagai sistem proteksi robot. Pada sistem robot pemadam api yang dibangun, jarak aman disetting $12 \mathrm{~cm}$. Jarak aman ini berfungsi sebagai jarak minimal robot harus berhenti, walaupun diinstruksikan oleh user. Pengujian dilakukan 15 kali pada jarak setiap $2 \mathrm{~cm}$ sampai 30 $\mathrm{cm}$. Tabel 4 menunjukkan bahwa sensor ultrasonik pada robot pemadam api memiliki fungsi yang berjalan sesuai settingan awal.

Tabel 4. Pengujian sistem proteksi.

\begin{tabular}{cccc}
\hline Percobaan ke-. & $\begin{array}{c}\text { Jarak yang } \\
\text { terukur }(\mathrm{cm})\end{array}$ & $\begin{array}{c}\text { Jarak yang diukur } \\
\text { sensor }(\mathrm{cm})\end{array}$ & Respon robot \\
\hline 1 & 2 & 2 & Berhenti \\
2 & 4 & 4 & Berhenti \\
3 & 6 & 6 & Berhenti \\
4 & 8 & 8 & Berhenti \\
5 & 10 & 10 & Berhenti \\
6 & 12 & 12 & Berhenti \\
7 & 14 & 14 & Tidak berhenti \\
8 & 16 & 16 & Tidak berhenti \\
9 & 18 & 18 & Tidak berhenti \\
10 & 20 & 20 & Tidak berhenti \\
11 & 22 & 22 & Tidak berhenti \\
12 & 24 & 24 & Tidak berhenti \\
13 & 26 & 26 & Tidak berhenti \\
14 & 28 & 28 & Tidak berhenti \\
15 & 30 & 30 & Tidak berhenti \\
\hline
\end{tabular}

\section{Kesimpulan}

Rancang bangun robot pendeteksi dan pemadam api telah diimplementasikan. Data yang diambil adalah data sensor ultrasonik, modul bluetooth, PWM dari motor DC dan sensor flame detector. Sensor ultrasonik sebagai sistem proteksi dari robot dan sensor flame detector sebagai sensor untuk mendeteksi api. Setelah mengimplementasikan dan pengujian robot didapatkan hasil pengujian dari sensor ultrasonik HC-SR 04. Total error yang didapat pada sensor ultrasonik yaitu 2,9\% karena tingkat error sedikit sistem proteksi pada robot sangat tinggi. Kemudian, hasil dari pengujian sensor flame detector KY-026 adalah robot mampu mendeteksi api dengan jarak sejauh $30 \mathrm{~cm}$ akan tetapi robot akan memadamkannya saat robot berjarak $12 \mathrm{~cm}$ dengan sumber api. 


\section{Referensi}

[1] S. dan Indra Gunawan, "Robot pemadam api menggunakan sensor ultrasonic dan flame sensor berbasis mikrokontroler arduino uno," Jurnal Ilmiah Trendtech, vol. 2, no. 3, pp. 917, 2017.

[2] W. K. Syahrul Yoga Pradana, Fitri Utaminingrum, "Deteksi titik api terpusat menggunakan kamera dengan notifikasi berbasis sms gateway pada raspberry pi," Jurnal Pengembangan Teknologi Informasi dan Ilmu Komputer, vol. Vol. 2, no. No. 12,, pp. 7183-7191, Desember 2018.

[3] H. S. Amri, "Sensor uvtron sebagai pendeteksi api pada robot pemadam api berbasis mikrokontroler atmega8535," Ph.D. dissertation, Universitas Sebelas Maret, 2016.

[4] E. Safrianti, R. Amri, and S. Budiman, "Prototype robot pemadam api beroda menggunakan teknik navigasi wall follower," Jurnal Rekayasa Elektrika, vol. 10, no. 2, pp. 83-91, 2012.

[5] F. Suryatini and J. Kustija, "Robot cerdas pemadam api menggunakan ping ultrasonic range finder dan uvtron flame detector berbasis mikrokontroler atmega 128," electrans, vol. 12, no. 1, pp. 29-38, 2013.

[6] M. D. Tobi, "Rancang bangun robot beroda pemadam api menggunakan arduino uno rev. 1.3," Electro Luceat, vol. 1, no. 1, 2015.

[7] Ikhsan, "Implementasi robot avoider dalam robot lien follower berbasis robot edukasi atmega32," Jurnal Teknologi Informasi dan Pendidikan, vol. 9, no. 3, pp. 50-58, 2016. 